\title{
A Transitory Cottony Variant of Rhizoctonia solani from Rice
}

\author{
Wu-hsiung TSAI* and Wen-hsiung Ko** \\ Wu-hsiung Tsai*・Wen-hsiung $\mathrm{Ko}^{* *}$ :イネから分離した Rhizoctonia \\ solani 菌の綿毛状変異株
}

\begin{abstract}
Cultures of single mycelial fragments from the cottony mycelial mass of Rhizoctonia solani occurring on rice plants with sheath blight consisted of a new cottony type and the ordinary type. The new variant reverted to the ordinary type in every case before it covered the petri plate. It was pathogenic to rice plants and the transitory nature of the organism also occurred in the parasitic phase of the life cycle.
\end{abstract}

(Received January 5, 1983)

Key Words : Rhizoctonia solani, sheath blight, variant.

\section{Introduction}

Sheath blight of rice caused by Rhizoctonia solani Kühn is a serious disease in Taiwan. Recently an unusual variant of $R$. solani was noticed on the blighted plants of the cultivars Tainan 5 and Chi-nung-shen 8 at the booting stage in the experimental farm in Chia-yi. The fungus formed cottony mycelial masses over disease lesions on leaf blades and sheaths (Fig. 1). Sometimes mycelial masses occurred on healthy leaf blades or sheaths several centimeters away from the sheath blight lesions. In the later growth stage mycelial masses became yellowish brown and were easily deformed by wind and rain. It represents a variant of $R$. solani different from those reported previously ${ }^{1,3,4,8)}$. The unique characters of this new variant of $R$. solani were examined in this study.

\section{Materials and Methods}

Isolation of mycelial fragments. A small amount of mycelia (ca. $1 \mathrm{~mm}$ diam) was removed with a pair of sterile dissecting forcepts with extra fine points from the center of a cottony mycelial mass produced on an infected rice plant. The mycelia were transferred to $10 \mathrm{ml}$ of sterile distilled water in a test tube and stirred with a needle for $4-5 \mathrm{~min}$. The test tube was placed on a whirlimixer for $2-3 \mathrm{~min}$ to break the mycelia into small fragments, and the mycelial fragments were plated on potato dextrose agar (PDA). After over night incubation at $28 \mathrm{C}$, plates were observed with

* Chia-yi Agricultural Experiment Station, Taiwan Agricultural Research Institute, Chia-yi, Taiwan.

** Department of Plant Pathology, Beaumont Agricultural Research Center, University of Hawaii, Hilo, Hawaii 96720, U.S. A. 


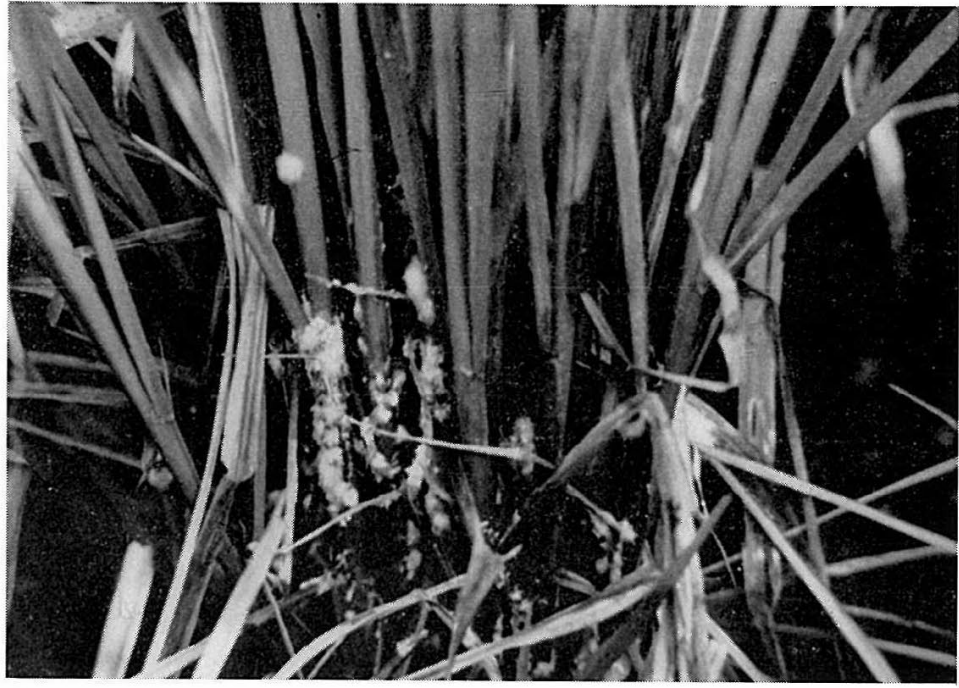

Fig. 1 Cottony mycelial masses on rice seedlings infected with sheath blight disease.

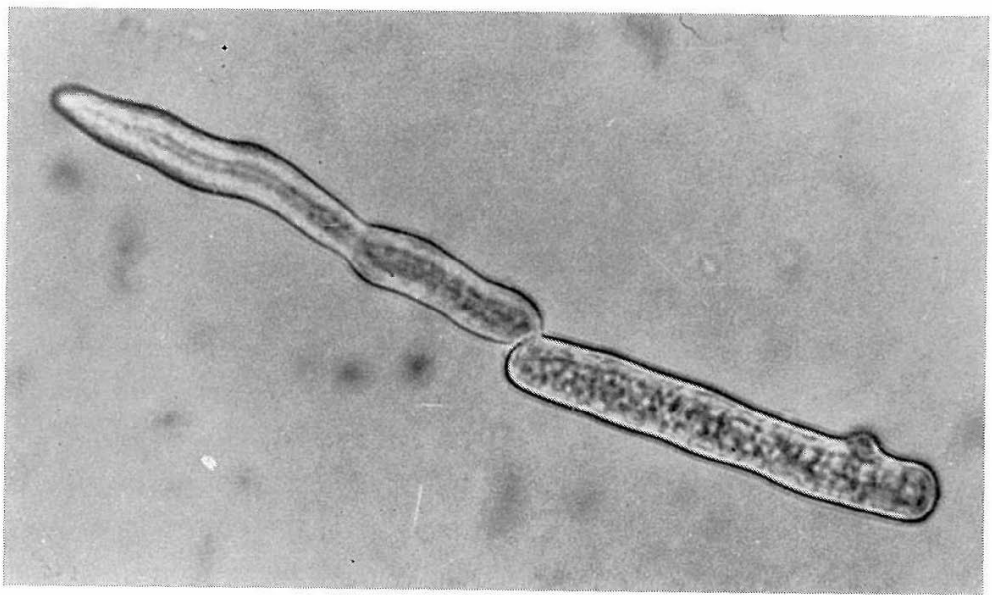

Fig. 2 A germinating mycelial fragment.

a microscope and those germinating mycelial fragments with one or two cells (Fig. 2) were each transferred to the center of PDA plate and further incubated for 10 days.

Pathogenicity test. Rice seedlings of the cultivar Tainan 5 grown in $12-\mathrm{cm}$ pots for 50 days were inoculated with the cottony type of $R$. solani by inserting a sclerotium in between the second leaf sheath and the stem. Inoculated plants were covered with plastic cages $(55 \times 55 \times 45 \mathrm{~cm})$ and watered twice a day. Data were recorded after 10 -day incubation. Control seedlings were treated similarly.

\section{Results and Discussion}

Of the 35 cultures of single mycelial fragments obtained from cottony mycelial masses on rice plants, 2 were the ordinary and 33 were the new cottony type forming loose 


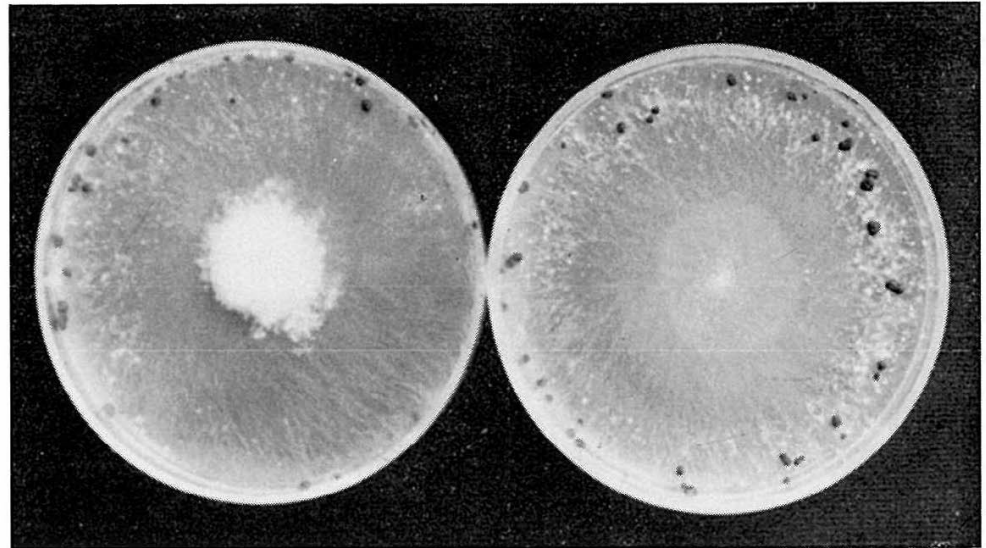

Fig. 3 Colony appearance of the cottony type (left) and the ordinary type of Rhizoctonia solani on potato dextrose agar.

whitish mycelial mass at the center of the colony (Fig. 3). The mycelial mass became yellowish brown and flattened when the culture grew old. Mycelia of both cottony and ordinary types have the characteristics of $R$. solani such as constriction at the base of the branch and formation of a septum in the branch near the point of origin ${ }^{9)}$. Moreover, cells of 10-day-old mycelia of both types were multinucleate ranging from 3-21 nuclei/cell, when the staining method of $\mathrm{Tu}$ and Kimbrough ${ }^{10)}$ was used.

The new variant of $R$. solani is unstable. Before it had covered a $9 \mathrm{~cm}$ petri plate, the fungus had reverted to the ordinary type in every case. Pieces of agar culture ( $5 \mathrm{~mm}$ diam) obtained from the colony margin of a cottony type were placed on water agar plates. After $48 \mathrm{hr}, 100$ hyphal tips were transferred to PDA plates. All the single hyphal tip cultures were the ordinary type. The experiment was repeated three times with the same results. Moreover, some mycelia in the whitish mycelial mass at the colony center of a cottony type also reverted to the ordinary type. Of 46 cultures of single mycelial fragments obtained, 32 were the cottony type and 14 were the ordinary type. The experiment was repeated 8 times with similar results.

When rice sccdlings of Tainan 5 cultivar were inoculated with sclerotia of the new variant produced on mycelial mass in the colony center, 9 of 10 inoculated tillers formed lesions on leaf sheaths and 3 of the diseased tillers were with cottony mycelial masses on the lesions. No such mycelial masses were found on the other 6 diseased tillers. Control seedlings remained healthy. When sclerotia on the colony margin were used as inocula, again 9 of 10 inoculated tillers formed lesions on leaf sheath, but cottony mycelial masses were not found on any of the diseased tillers. Cultures of single mycelial fragments were derived from the mycelial mass of an inoculated plant. Of the 68 cultures obtained 62 were the cottony type and 6 were the ordinary type. Similar results were obtained when seedlings of cultivar Taichung-shen 3 were inoculated. These results show that the new variant of $R$. solani is pathogenic to rice and that the transitory nature of the organism also occurs in the parasitic phase of the life cycle.

The origin of the new variaut of $R$. solani is still unknown. Spontaneous mutation in $R$. solani has been observed in culture, but not in nature ${ }^{5,6)}$. The new variant described 
in this report could have originated from a heterokaryon resulting from anastomosis between two homokaryons ${ }^{2,6,7,11)}$. Although most heterokaryons are stable, reversion of heterokaryon formed from two morphological mutants to cultural morphology of an original mutant has been observed in culture ${ }^{6}$.

\title{
Literature cited
}

1. Akai, S., Ogura, H. and Sato, T. (1960). Ann. Phytopath. Soc. Japan 25: 125-130.

2. Anderson, N. A., Stretton, H. M., Groth, J. V. and Flentje, N. T. (1972). Phytopathology 62 : 1057-1065.

3. Baker, K. F. (1970). In Rhizoctonia solani: Biology and Pathology (Parmeter, J. R. Jr. ed.). Univ. Calif. Press, Berkeley. pp. 125-148.

4. Chien, C. C. and Ching, S. C. (1963). Agric. Res. Taiwan 12 (2): 1-6.

5. Flentje, N. T., Stretton, H. M. and McKenzie, A. R. (1967). Aust. J. Biol. Sci. 20: 1173-1180.

6. Flentje, N. T., Stretton, H. M. and McKenzie, A. R. (1970). In Rhizoctonia solani: Biology and Pathology (Parmeter, J. R. Jr. ed.). Univ. Calif. Press, Berkeley. pp. 52-65.

7. McKenzie, A. R., Flentje, N. T., Stretton, H. M. and Mayo, M. J. (1969). Aust. J. Biol. Sci. 22 : 895-904.

8. Ou, S. H. 1972. Rice Diseases. Commonw. Mycol. Inst., Kew. pp. 256-268.

9. Parmeter, J. R., Jr. and Whitney, H. S. (1970). In Rhizoctonia solani: Biology and Pathology (Parmeter, J. R. Jr. ed.). Univ. Calif. Press, Berkeley. pp. 7-19.

10. Tu, C. C. and Kimbrough, J. W. (1973). Mycologia 65: 941-944.

11. Whitney, H. S. and Parmeter, J. R., Jr. (1963). Can. J. Bot. 41: 879-886.

\section{和 文 摘 要}

\section{イネから分離した Rhizoctonia solani 菌の綿毛状変異株}

\author{
Wu-hsiung Tsai $\cdot$ Wen-hsiung Ko
}

イネ体上の紋枯病病斑あるいはその周辺に生じた Rhizoctonia solani 菌の綿毛状菌系塊から単菌系片を分 離培養したところ, 培地上に綿毛状菌叢を形成するものと通常型の菌叢を形成するものがあった。綿毛状変 異株はいずれの場合でも菌丵の先端がシャーレ側壁に達するまでに通常型に戻った。本菌株はイネ体に対し て病原性を示し，また本菌の綿毛状菌糸の一過性はイネ体上でも発現した。 